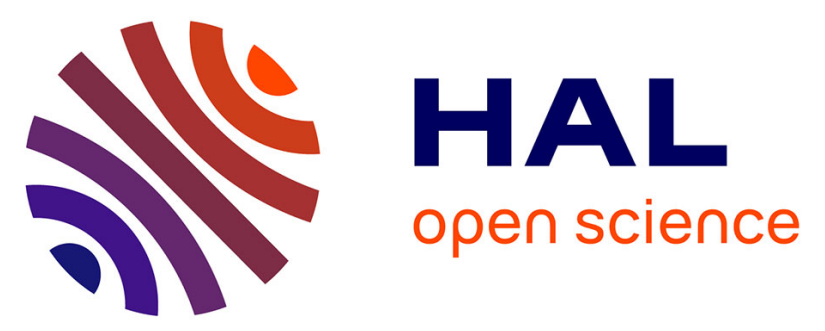

\title{
Composition of a thermal plasma formed from PTFE with copper in non-oxidant atmosphere. Part II: Comparison of a test case with nitrogen
}

Pascal André, Zacharie Koalaga

\section{- To cite this version:}

Pascal André, Zacharie Koalaga. Composition of a thermal plasma formed from PTFE with copper in non-oxidant atmosphere. Part II: Comparison of a test case with nitrogen. High Temperature Material Processes: An International Quarterly of High-Technology Plasma Processes, 2010, 14 (3), pp.289. hal-00537755

\section{HAL Id: hal-00537755 \\ https://hal.science/hal-00537755}

Submitted on 19 Nov 2010

HAL is a multi-disciplinary open access archive for the deposit and dissemination of scientific research documents, whether they are published or not. The documents may come from teaching and research institutions in France or abroad, or from public or private research centers.
L'archive ouverte pluridisciplinaire HAL, est destinée au dépôt et à la diffusion de documents scientifiques de niveau recherche, publiés ou non, émanant des établissements d'enseignement et de recherche français ou étrangers, des laboratoires publics ou privés. 


\title{
Composition of a thermal plasma formed from PTFE with copper in non-oxidant atmosphere. \\ Part II: Comparison of a test case with nitrogen
}

\author{
P. ANDRE $^{1}$ and Z. KOALAGA ${ }^{2}$ \\ ${ }^{1}$ Clermont Université, Université Blaise Pascal, LAEPT, BP 10448, F-63000 CLERMONT- \\ FERRAND, France \\ ${ }^{2}$ LAME, Ouagadougou University, 03 BP7021, OUAGADOUGOU, Burkina Faso
}

\begin{abstract}
The aim of this work is to compare the main characteristic of good dielectric gas defined in our previous paper with nitrogen gas. We study the molar fraction of chemical species in PTFE, $\mathrm{N}_{2}$ and $\mathrm{Cu}$ mixture for several proportions and pressures. We show that the nitrogen gas does not satisfy the characteristic of good dielectric leading to the manufacturer to modify entirely the electrical isolating set up.
\end{abstract}

Key Words: circuit breakers, nitrogen, PTFE, carbon formation, copper, dielectric gas, plasma composition.

\section{Introduction}

In our previous paper we have define a test case with the $\mathrm{SF}_{6}, \mathrm{PTFE}$ and $\mathrm{Cu}$ to choose the better insulating compounds [1]. As a matter of fact the $\mathrm{SF}_{6}$ gas is widely used for electrical insulating and in high voltage circuit breakers [2-6]. The environmental impact and the life cycle cost are, at the present time, keys for new markets. So the competition between industries is high for their image and for the purchasers to find alternatives.

Studying the electrical breakdown strength of nitrogen and $\mathrm{SF}_{6}$ with Pashen curves [7], one can think that playing with the pressure we can obtain the same breakdown strength. That is to say with a higher pressure the electrical breakdown strength of nitrogen is the same as the electrical breakdown strength of $\mathrm{SF}_{6}$. For the test case with $\mathrm{SF}_{6}, \mathrm{PTFE}$ and $\mathrm{Cu}$ we have shown that we have to avoid the production of condensed matter and have a good proportion of electronegative species decreasing the electrons mobility [1]. The composition results can give available indications. Consequently, the study of the composition for $\mathrm{N}_{2}$, PTFE and $\mathrm{Cu}$ with a pressure of 1 to 30 bars is useful.

First we explicit the chosen chemical species and the massic enthalpy calculation with condensed phase. Secondly, we study the results for three mixtures case 1: $1 \%\left(\mathrm{C}_{2} \mathrm{~F}_{4}\right)_{\mathrm{n}}, 98 \%$ $\mathrm{N}_{2}, 1 \% \mathrm{Cu}$; case 2: $50 \%\left(\mathrm{C}_{2} \mathrm{~F}_{4}\right)_{\mathrm{n}}, 49 \% \mathrm{~N}_{2}, 1 \% \mathrm{Cu}$ and case $3: 98 \%\left(\mathrm{C}_{2} \mathrm{~F}_{4}\right)_{\mathrm{n}}, 1 \% \mathrm{~N}_{2}, 1 \% \mathrm{Cu}$ in weight percentage and for the case 2 with three pressure 1, 10 and 30 bars. Finally, we give a conclusion.

\section{Chemical species and enthalpy calculation}

In our calculation, for the $\mathrm{N}_{2}$, PTFE, $\mathrm{Cu}$ mixtures, 11 monatomic species are taken into account: $\mathrm{C}, \mathrm{C}^{-}, \mathrm{C}^{+}, \mathrm{Cu}, \mathrm{Cu}^{-}, \mathrm{Cu}^{+}, \mathrm{F}, \mathrm{F}^{-}, \mathrm{F}^{+}, \mathrm{N}, \mathrm{N}^{+}$and electrons, 17 diatomic species: $\mathrm{C}_{2}, \mathrm{C}_{2}^{-}$, $\mathrm{C}_{2}^{+}, \mathrm{CF}, \mathrm{CF}^{+}, \mathrm{CN}, \mathrm{CN}^{-}, \mathrm{CN}^{+}, \mathrm{Cu}_{2}, \mathrm{CuF}, \mathrm{F}_{2}, \mathrm{~F}_{2}^{-}, \mathrm{F}_{2}^{+}, \mathrm{FN}, \mathrm{N}_{2}, \mathrm{~N}_{2}^{-}, \mathrm{N}_{2}^{+}$and 25 polyatomic species : $\mathrm{C}_{2} \mathrm{~F}_{2}, \mathrm{C}_{2} \mathrm{~F}_{3} \mathrm{~N}, \mathrm{C}_{2} \mathrm{~F}_{4} . \mathrm{txt}, \mathrm{C}_{2} \mathrm{~F}_{6}, \mathrm{C}_{2} \mathrm{~N}, \mathrm{C}_{2} \mathrm{~N}_{2}, \mathrm{C}_{3}, \mathrm{C}_{4}, \mathrm{C}_{4} \mathrm{~N}_{2}, \mathrm{C}_{5}, \mathrm{CF}_{2}, \mathrm{CF}_{2}^{+}$, $\mathrm{CF}_{3}, \mathrm{CF}_{3}{ }^{+}, \mathrm{CF}_{4}, \mathrm{CFN}, \mathrm{CNN}, \mathrm{CuF}_{2}, \mathrm{~F}_{2} \mathrm{~N}, \mathrm{~F}_{2} \mathrm{~N}_{2} \mathrm{C}_{2}, \mathrm{~F}_{2} \mathrm{~N}_{2}-\mathrm{T}, \mathrm{F}_{3} \mathrm{~N}, \mathrm{~F}_{4} \mathrm{~N}_{2}, \mathrm{~N}_{3}, \mathrm{NCN}$. For solid and 
liquid phase we take the carbon solid, liquid copper and solid copper into account. As in our previous paper, the thermodynamic properties versus temperature are taken from [8] for solid and liquid copper. The thermodynamic properties for solid carbon are those of the graphite taken from [8]. For the gaseous polyatomic species data are taken from [8]. For the monatomic and diatomic species the thermodynamic properties are calculated from the partition functions [9]. The enthalpies of formation are taken in [8].

To determine the composition we used the numerical method as described in [1, 10]. Concerning the enthalpy since we have solid and liquid phase we calculated it by unit of mass.

$$
H=\left(\frac{\sum_{i=1}^{N} x_{i} h_{i}+\Delta H}{\sum_{i=1}^{N} x_{i} m_{i}}\right)
$$

Where $x_{i}$ the molar fraction, $h_{i}$ the specific enthalpy of chemical species, $m_{i}$ the molar weight and $\Delta H$ the enthalpy correction due to Debye effect that is very low in our temperature range

\section{II. $\mathbf{N}_{2},\left(\mathbf{C}_{2} \mathbf{F}_{4}\right)_{n}$, Cu mixtures}

\section{II.1 Influence of stoichiometric parameters.}

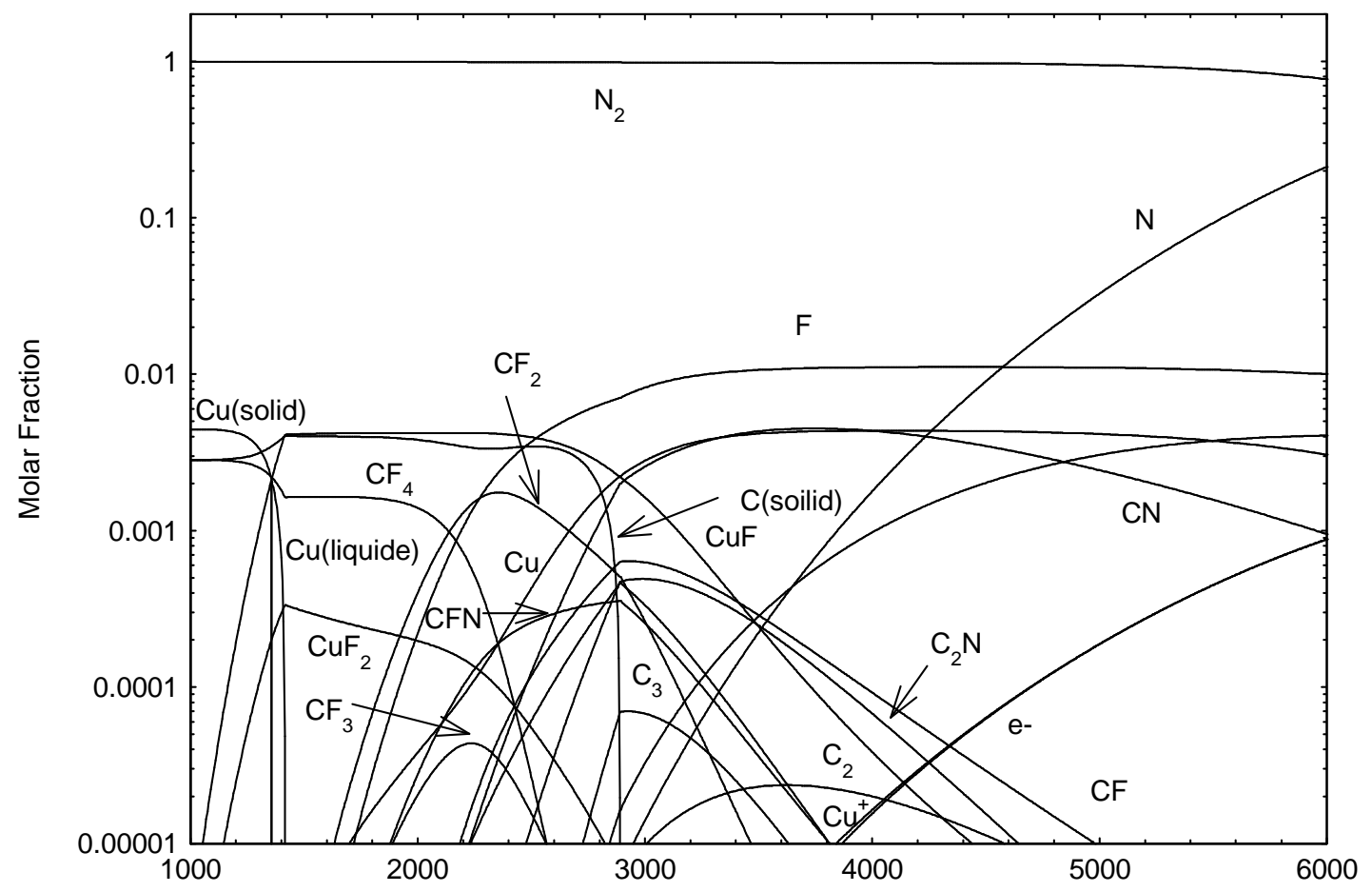

Figure 1.a: Molar fraction versus temperature at 1 bar for a mixture of $1 \%\left(\mathrm{C}_{2} \mathrm{~F}_{4}\right)_{\mathrm{n}}, 98 \% \mathrm{~N}_{2}$, $1 \% \mathrm{Cu}$ in weight percentage. 


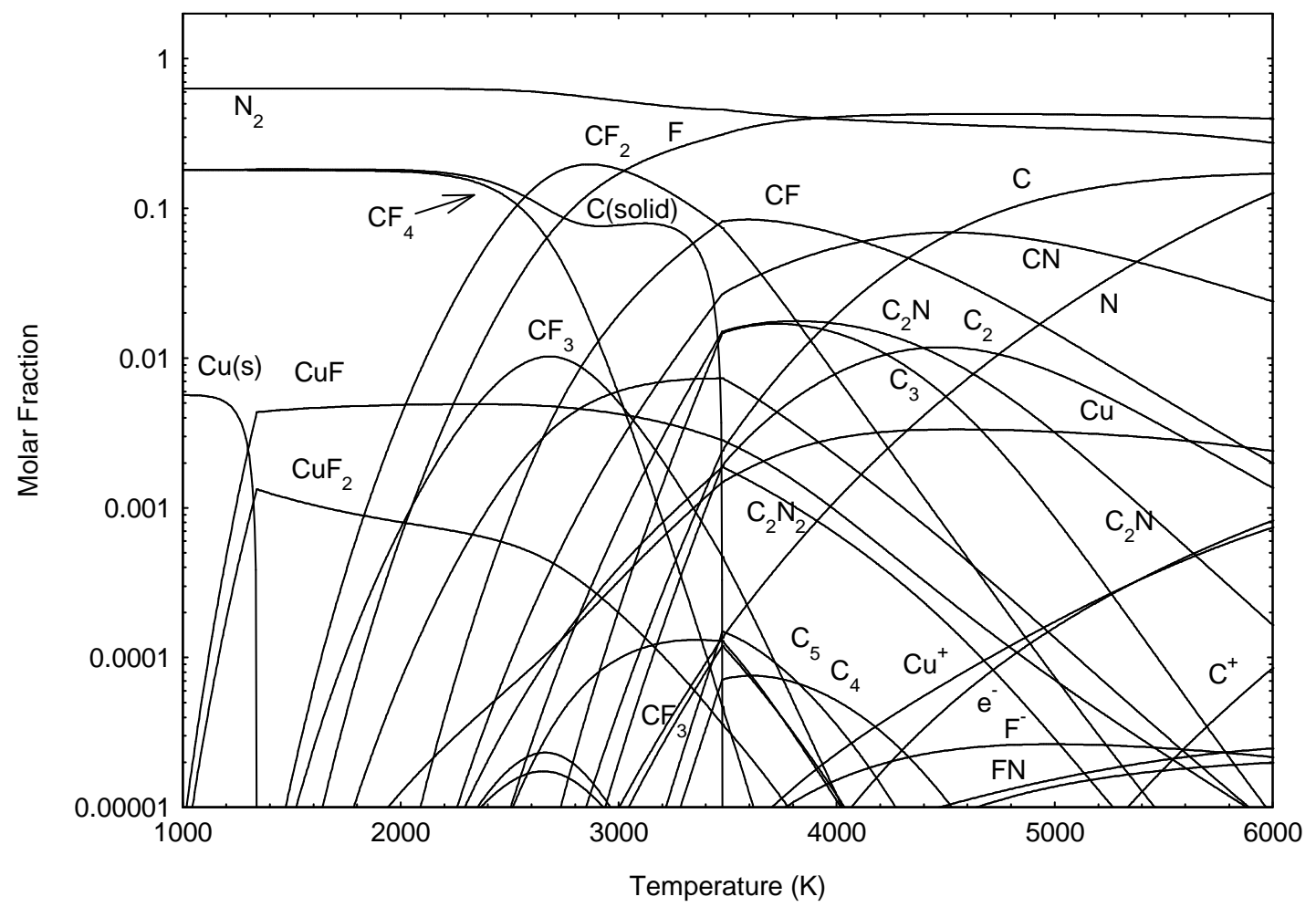

Figure 1.b: Molar fraction versus temperature at 1 bar for a mixture of $50 \%\left(\mathrm{C}_{2} \mathrm{~F}_{4}\right)_{\mathrm{n}}, 49 \% \mathrm{~N}_{2}$ , $1 \% \mathrm{Cu}$ in weight percentage.

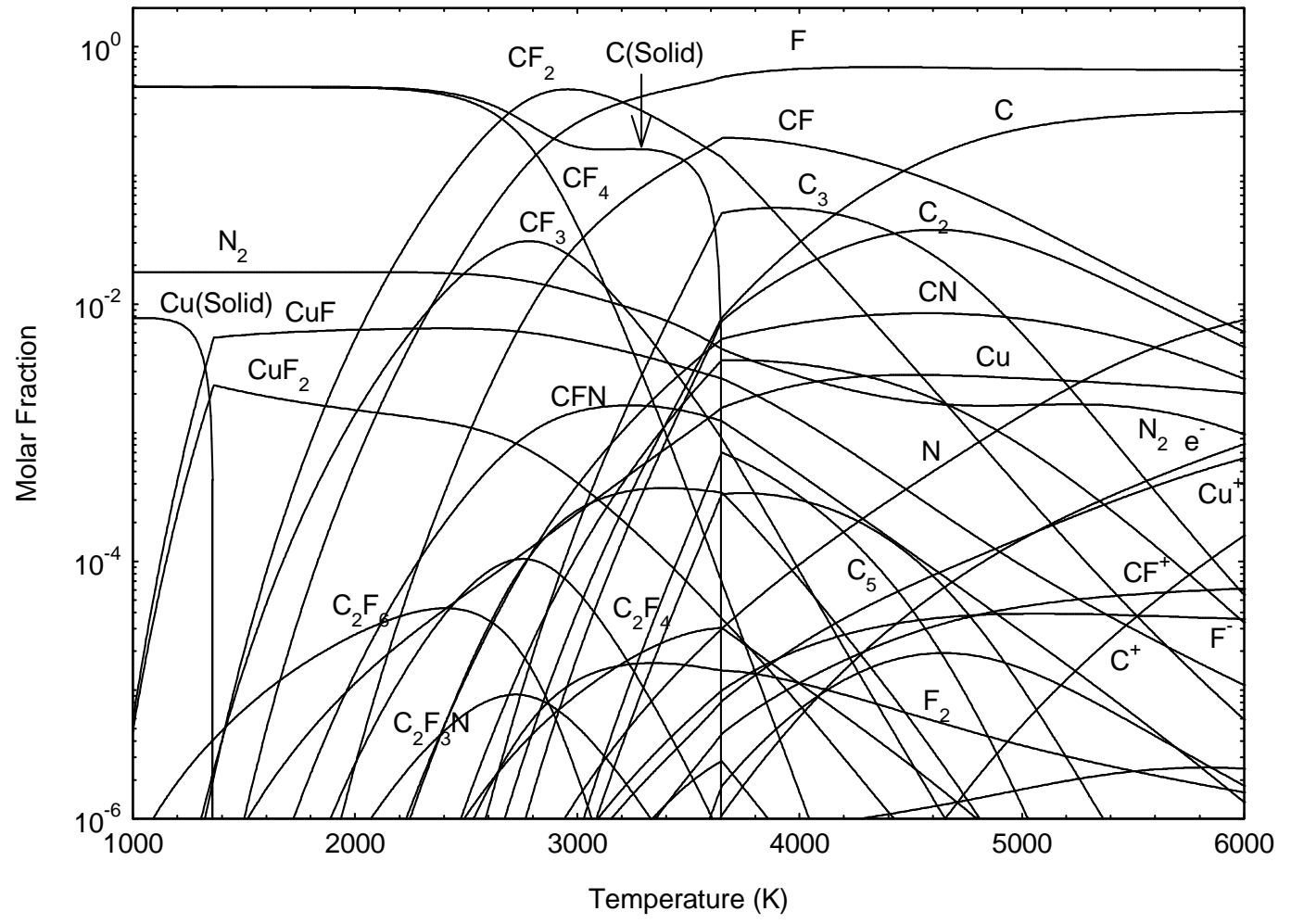

Figure 1.c: Molar fraction versus temperature at 1 bar for a mixture of $98 \%\left(\mathrm{C}_{2} \mathrm{~F}_{4}\right)_{\mathrm{n}}, 1 \% \mathrm{SF}_{6}$, $1 \% \mathrm{Cu}$ in weight percentage.

In figure 1, the molar fraction has been plotted for three mixtures based on $\mathrm{N}_{2}$, PTFE and copper. In the case $1,1 \%\left(\mathrm{C}_{2} \mathrm{~F}_{4},\right)_{\mathrm{n}}, 98 \% \mathrm{~N}_{2}, 1 \% \mathrm{Cu}$ in weight percentage, the main chemical 
species is the Nitrogen $\mathrm{N}_{2}$. We observe condensed phase liquid and solid copper and carbon solid in the considered temperature range. The $\mathrm{N}_{2}$ molecules does not dissociate at a high rate in the considered temperature range. The carbon solid sublimates in Cyanogen $\mathrm{CN}$ around 2890K. The solid copper sublimates in $\mathrm{CuF}$ before to be liquefied. For temperature higher than $3000 \mathrm{~K}$ the main species are $\mathrm{N}_{2}, \mathrm{~N}$ and $\mathrm{F}$. For the charged particles, the electrical neutrality is reached between $\mathrm{e}^{-}$and $\mathrm{Cu}^{+}$.

In the case $2,50 \%\left(\mathrm{C}_{2} \mathrm{~F}_{4}\right)_{\mathrm{n}} 49 \% \mathrm{~N}_{2} 1 \% \mathrm{Cu}$, the main chemical species are $\mathrm{N}_{2}, \mathrm{CF}_{4}$, solid carbon and solid copper. The $\mathrm{CF}_{4}$ molecules dissociate in $\mathrm{CF}_{2}$ and $\mathrm{F}$ at a temperature around $2500 \mathrm{~K}$. Equilibrium is reach between $\mathrm{CF}_{2}$ molecules, $\mathrm{F}$ and carbon solid until $3480 \mathrm{~K}$ when carbon sublimates. For this temperature the $\mathrm{CF}_{2}$ molecules dissociates in $\mathrm{CF}$ and $\mathrm{F}$. The solid copper sublimates in $\mathrm{CuF}$ and $\mathrm{CuF}_{2}$ at a temperature of $1350 \mathrm{~K}$. For the higher temperature at $6000 \mathrm{~K}$ the main chemical species are $\mathrm{N}_{2}, \mathrm{~F}, \mathrm{C}, \mathrm{N}, \mathrm{CN}, \mathrm{CF}, \mathrm{Cu}$ and $\mathrm{C}_{2}$. The electrical neutrality is reach between $\mathrm{Cu}^{+}$and $\mathrm{F}^{-}$for the temperature lower than $4250 \mathrm{~K}$ and $\mathrm{e}^{-}$and $\mathrm{Cu}^{+}$ for the higher temperature in the considered temperature range.

In the case $3,98 \%\left(\mathrm{C}_{2} \mathrm{~F}_{4},\right)_{\mathrm{n}} 1 \% \mathrm{~N}_{2} 1 \% \mathrm{Cu}$, the main chemical species are solid carbon, $\mathrm{CF}_{4}$, Nitrogen $\mathrm{N}_{2}$ and solid copper at low temperature. The $\mathrm{CF}_{4}$ molecules dissociate in $\mathrm{CF}_{2}$ and $\mathrm{F}$ at a temperature around $2650 \mathrm{~K} . \mathrm{CF}_{2}$ molecules dissociate in solid carbon and $\mathrm{F}$ between 3050 $\mathrm{K}$ and $3700 \mathrm{~K}$. Thus the molar fraction of solid carbon is stable in this temperature range. At $3685 \mathrm{~K}$, when solid carbon sublimates in $\mathrm{CF}$ and $\mathrm{C}_{3}$, the $\mathrm{CF}_{2}$ molecules dissociate in $\mathrm{CF}$ and F. Around $4470 \mathrm{~K}, \mathrm{CF}$ dissociates in $\mathrm{C}$ and $\mathrm{F}$. The solid copper sublimates in $\mathrm{CuF}$ and $\mathrm{CuF}_{2}$ at a temperature of $1418 \mathrm{~K} 1350 \mathrm{~K}$. For the higher temperature $6000 \mathrm{~K}$ the species are monatomic $\mathrm{F}, \mathrm{C}, \mathrm{CF}, \mathrm{CN}, \mathrm{C}_{2}$ and $\mathrm{Cu}$. The electrical neutrality is reach between $\mathrm{Cu}^{+}$and $\mathrm{F}^{-}$ for the temperature lower than $4500 \mathrm{~K}$ and $\mathrm{e}^{-}$and $\mathrm{Cu}^{+}$for the higher temperature in the considered temperature range.

Comparing the three considered cases, we observe that in each case the carbon solid and the solid copper are presents. Modifying stoichiometric coefficients does not allow the creation of gaseous species with carbon avoiding the carbon solid. The $\mathrm{CF}_{4}$ molecules are present in each considered cases. The neutrality in gas phase is made at low temperature between $\mathrm{F}^{-}$and $\mathrm{Cu}^{+}$ and between $\mathrm{e}^{-}$and $\mathrm{Cu}^{+}$for the higher temperature in the considered temperature range.

\section{II.2 Influence of the pressure}

In figure 2 , in the case of $50 \%\left(\mathrm{C}_{2} \mathrm{~F}_{4}\right)_{\mathrm{n}}, 49 \% \mathrm{~N}_{2}, 1 \% \mathrm{Cu}$ in weight percentage for two pressures 10 bars and 30 bars, the molar fraction are plotted versus the temperature. The dissociation of $\mathrm{CF}_{4}$ in $\mathrm{CF}_{2}$ and $\mathrm{F}$ is made at $2540 \mathrm{~K}$ for $1 \mathrm{bar}, 2790 \mathrm{~K}$ for 10 bars and $2920 \mathrm{~K}$ at 30 bars. The carbon solid sublimates of at $3475 \mathrm{~K}$ for 1 bar, at $3630 \mathrm{~K}$ for 10 bars and at $3670 \mathrm{~K}$ for 30 bars. The $\mathrm{CF}_{2}$ dissociates in $\mathrm{CF}$ and $\mathrm{F}$ around $3460 \mathrm{~K}$ at 1 bar, $3560 \mathrm{~K}$ at 10 bars and $3830 \mathrm{~K}$ at 30 bars. $\mathrm{CF}$ dissociates in $\mathrm{C}$ and $\mathrm{F}$ around $4100 \mathrm{~K}$ for 1 bar, $3940 \mathrm{~K}$ at 10 bars and $4220 \mathrm{~K}$ at 30 bars. The solid copper sublimates and liquid copper vaporized in $\mathrm{CuF}$ and $\mathrm{CuF}_{2}$ at a temperature of $1340 \mathrm{~K}$ at 1 bar, $1470 \mathrm{~K}$ at 10 bars and $1545 \mathrm{~K}$ for 30 bars. For the higher temperature $6000 \mathrm{~K}$, we observe that the higher the pressure the higher the molecule molar fractions. So the main species for $6000 \mathrm{~K}$ at 1 bar are F, $\mathrm{N}_{2}, \mathrm{C}, \mathrm{N}, \mathrm{CN}, \mathrm{CF}, \mathrm{Cu}$ and $\mathrm{C}_{2}$ and for 30 bars $\mathrm{N}_{2}, \mathrm{~F}, \mathrm{C}, \mathrm{CF}, \mathrm{CN}, \mathrm{N}, \mathrm{C}_{2} \mathrm{~N}, \mathrm{C}_{2}$, and $\mathrm{Cu}$. The electrical neutrality is reach between $\mathrm{Cu}^{+}$and $\mathrm{F}^{-}$for the temperature lower than $4250 \mathrm{~K}$ and $\mathrm{e}^{-}$and $\mathrm{Cu}^{+}$for the higher temperature in the considered temperature range at 1 bar. For 10 bars, the electrical neutrality is reach between $\mathrm{Cu}^{+}$and $\mathrm{F}^{-}$for the temperature lower than $5230 \mathrm{~K}$ and $\mathrm{e}^{-}$and $\mathrm{Cu}^{+}$for the higher temperature. For 30 bars, the electrical neutrality is made between $\mathrm{F}^{-}, \mathrm{CF}^{+}$and $\mathrm{Cu}^{+}$. 


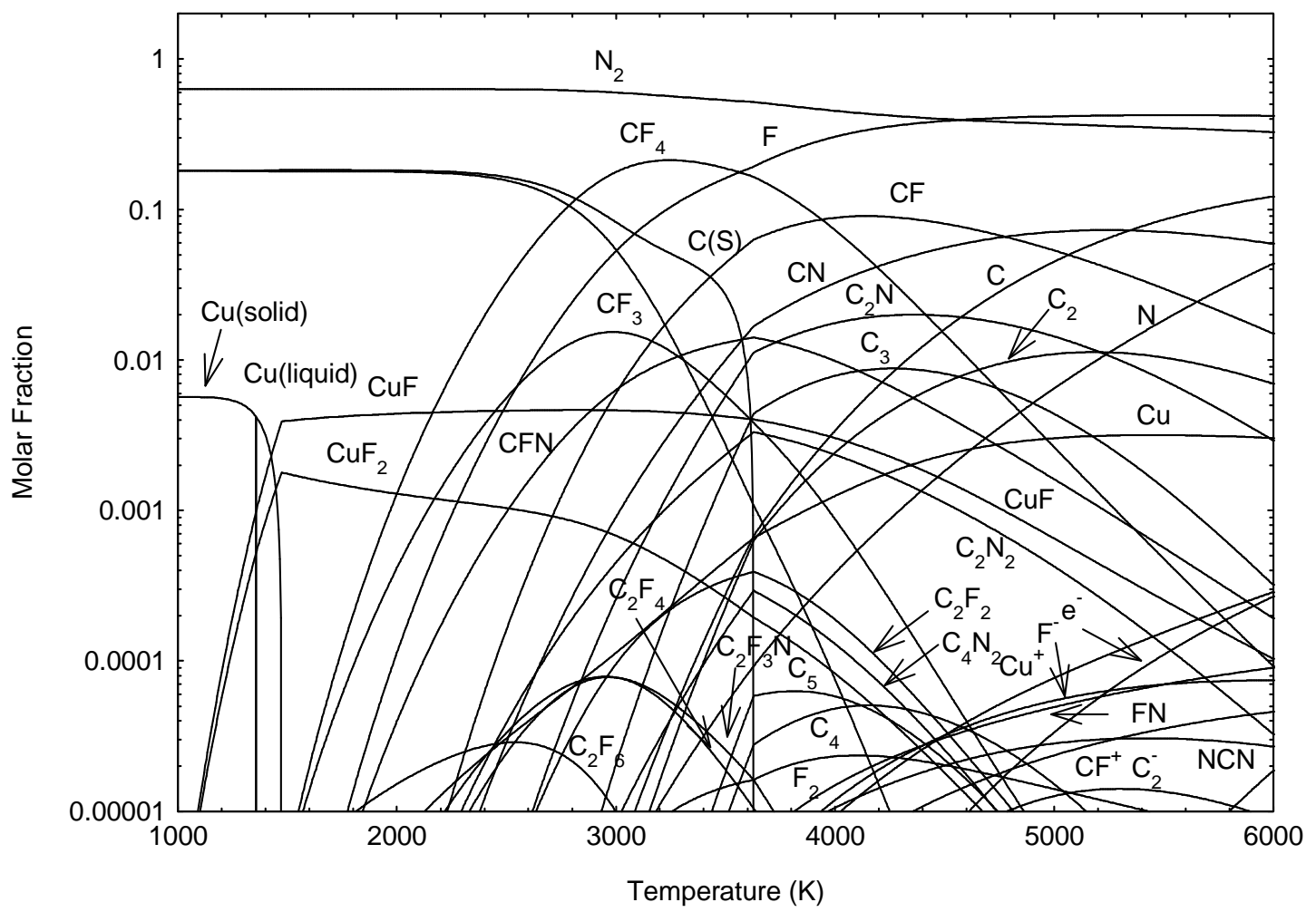

Figure 2.a: Molar fraction versus temperature at 10 bars for a mixture of $50 \%\left(\mathrm{C}_{2} \mathrm{~F}_{4}\right)_{\mathrm{n}}, 49 \%$ $\mathrm{N}_{2}, 1 \% \mathrm{Cu}$ in weight percentage.

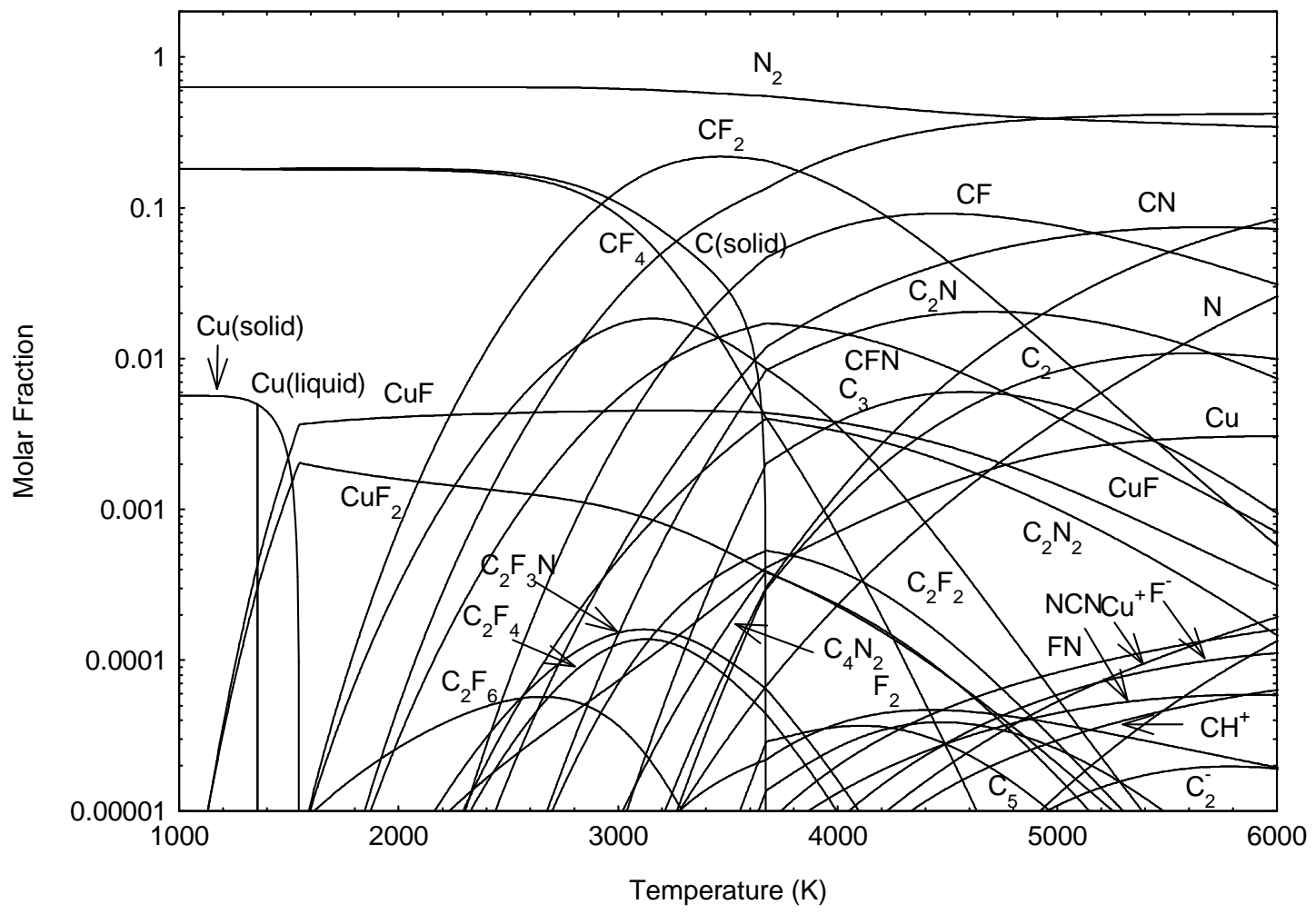

Figure 2.b: Molar fraction versus temperature at 30 bars for a mixture of $50 \%\left(\mathrm{C}_{2} \mathrm{~F}_{4}\right)_{\mathrm{n}}, 49 \%$ $\mathrm{N}_{2}, 1 \% \mathrm{Cu}$. 


\section{Massic Enthalpy}

In figure 3, we have plotted the massic enthalpy versus temperature for the three considered case the nitrogen and SF6 gas and three pressures for case 2. The nitrogen gas is considered as a reference gas with enthalpy of formation equal to zero [8] due to the fact that it is stable in atmosphere. The enthalpy of the $\mathrm{SF}_{6}$ gas has a variation of enthalpy between $1800 \mathrm{~K}$ and 4000 $\mathrm{K}$ due to dissociation of $\mathrm{SF}_{6}, \mathrm{SF}_{4}$, and $\mathrm{SF}_{2}[11,12]$. This variation of enthalpy is useful to extinguish an electrical arc since the electrical energy from the electrical circuit is consumed by the chemical reaction in the gas. Unlike the variation of enthalpy for the nitrogen gas monotonically increases in the considered temperature range. As a matter of fact no dissociation occurs. The same conclusion can be made for the mixture of the case $1,1 \%$ $\left(\mathrm{C}_{2} \mathrm{~F}_{4},\right)_{\mathrm{n}}, 98 \% \mathrm{~N}_{2}, 1 \% \mathrm{Cu}$ due to the fact that the main chemical species is the nitrogen (Fig 1. and 2). For the case 2 and case 3, the variation in enthalpy in the temperature range is due to the sublimation of solid carbon and to the dissociation of $\mathrm{CF}_{4}$ and $\mathrm{CF}_{2}$. (Fig 1 and 2).

The increase in the enthalpy is due to the chemical reaction. The higher the pressure the higher the temperature when the chemical reaction occurs. In figure $3 \mathrm{~b}$, we have plotted the massic enthalpy versus temperature in the case $2, \mathrm{SF}_{6}$ and nitrogen for three pressures 1,10 and 30 bars. The variation of enthalpy in $\mathrm{SF}_{6}$ gas is due to the dissociations of gaseous species $\mathrm{SF}_{6}, \mathrm{SF}_{4}$, and $\mathrm{SF}_{2}$, so since the pressure increase the dissociation reactions are made at higher temperature. Concerning the case 2 the increases in enthalpy is due to the carbon sublimation and to dissociation of gaseous species $\mathrm{CF}_{4}$ and $\mathrm{CF}_{2}$. Even the sublimation is abrupt (Fig 1 and 2) no shark increases in enthalpy is observed. As a matter of fact around the same temperature \# 4000K the gaseous dissociation occurs. With the increase of pressure the enthalpy increases at higher temperature. Since no dissociation occurs in the temperature range 1000 to $5000 \mathrm{~K}$ no variation in enthalpy for nitrogen plasma is observed in this temperature range.

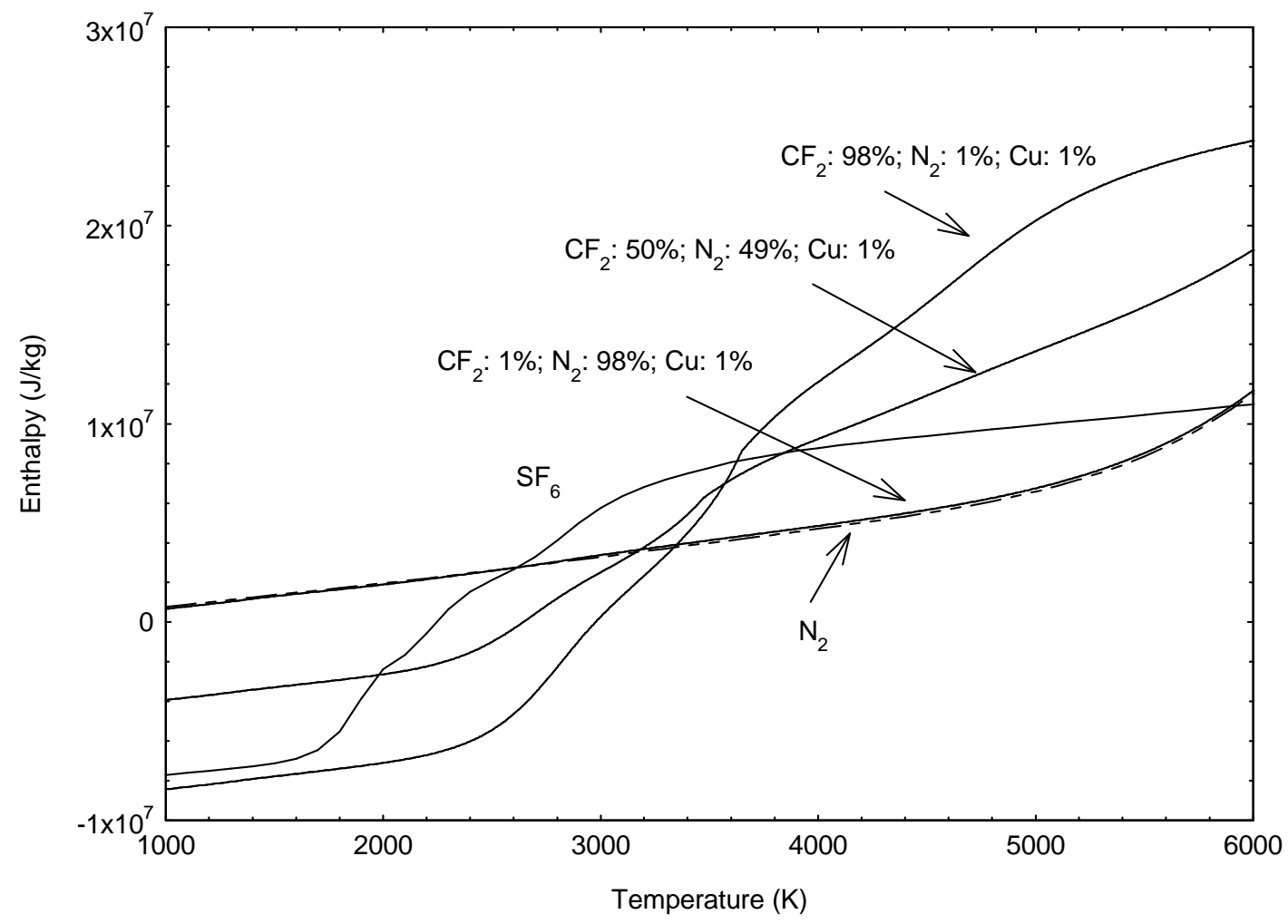

Figure 3.a: Massic enthalpy versus temperature at 1 bar for several mixtures, $\mathrm{SF}_{6}$ and $\mathrm{N}_{2}$ 


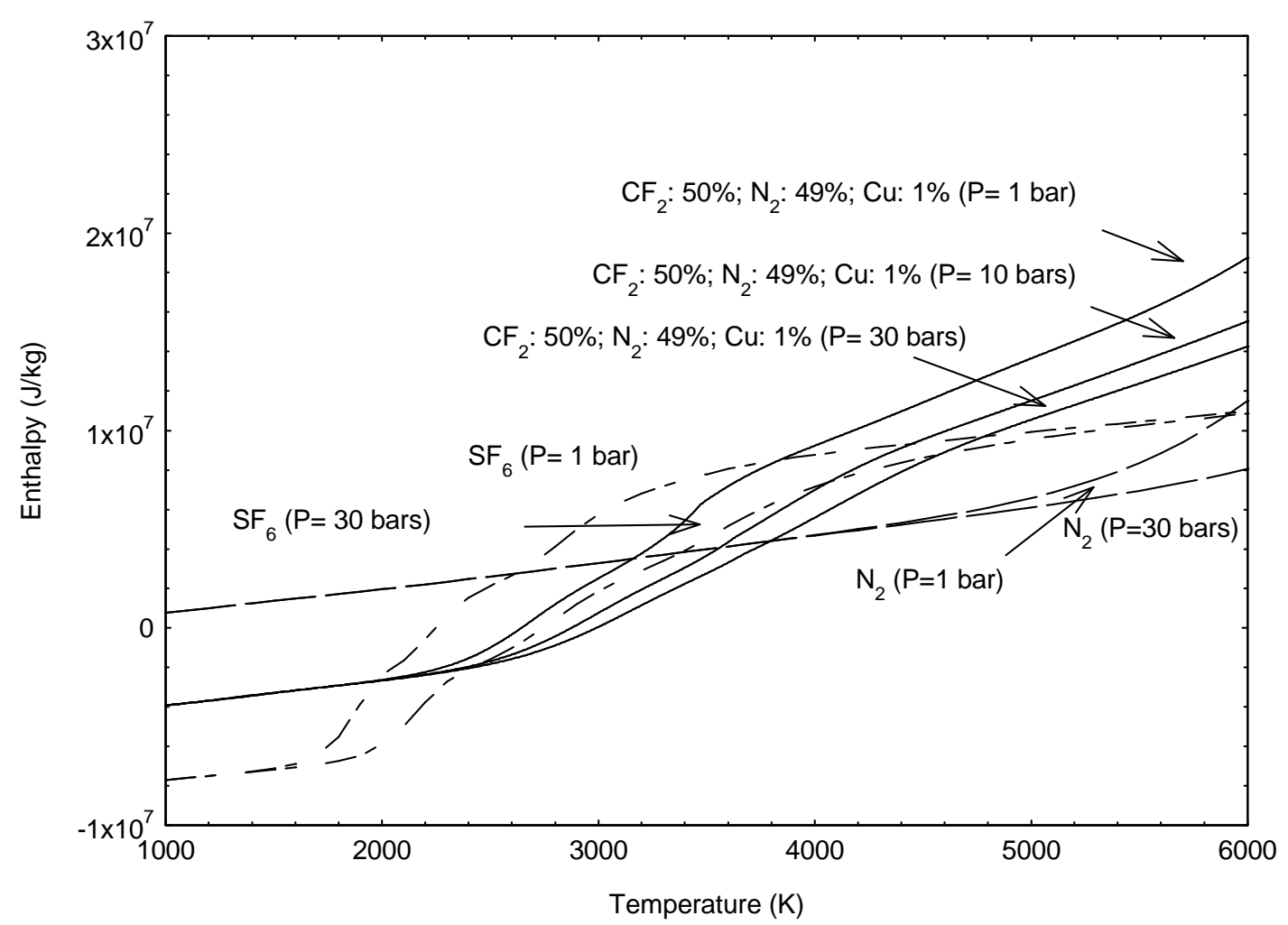

Figure 3.b: Massic enthalpy versus temperature for case $2, \mathrm{SF}_{6}$ and $\mathrm{N}_{2}$ at tree pressures $(1,10$ and 30 bars)

\section{Conclusion}

We have presented the molar fraction and massic enthalpy of mixture of PTFE, $\mathrm{N}_{2}$ and $\mathrm{Cu}$ for several proportions and pressures versus temperature. The industries since the $\mathrm{SF}_{6}$ have large environmental impact wish to replace the $\mathrm{SF}_{6}$ gas for their system (electrical insulating, circuit breakers). In our previous paper we have shown that a good proportion (stoichiometric variables) of $\mathrm{SF}_{6}$ in the mixture avoids the condensed phase [1 see also 13]. With nitrogen the condensed phase are always present. The system with nitrogen has to use a high pressure to clean and push the polluted gas far from the electrodes avoiding restriking. The energy gained by the gas flow can be similar between $\mathrm{SF}_{6}$ gas and nitrogen gas. This energy in the first case is due to the dissociation of $\mathrm{SF}_{6}, \mathrm{SF}_{4}$ and $\mathrm{SF}_{2}$ for $\mathrm{SF}_{6}$ gas and $\mathrm{CF}_{4}$ and $\mathrm{CF}_{2}$ and in the second case to sublimation of condensed carbon for mixture of $\mathrm{N}_{2}$, PTFE and Copper. The electronegative ions molar fraction is low due to the fact that the $\mathrm{N}^{-}$is unstable. Nevertheless, the electronegative ions are mainly due to the species from wall ablation. Finally, it seems that the nitrogen is not a god gas for electrical insulating in the existing system. To use the nitrogen, manufacturers have to change their electrical isolating set up.

\section{Acknowledgment:}

The authors wish to thank the European Edulink Program RAMSES for their financial support to help the development of scientific cooperation between Blaise Pascal University and University of Ouagadougou, and the two laboratories LAME and LAEPT. 


\section{References}

[1] P. André, Z. Koalaga, Composition of a thermal plasma formed from PTFE with copper in non-oxidant atmosphere. Part I: definition of a test case with the $S F_{6}, \mathrm{JHTMP}$, vol 14, issue $2,2010$.

[2] Chu, F. Y. SF6 Decomposition in Gas-Insulated Equipment IEEE Transactions on Electrical Insulation Issue: 5, Vol EI-21, p 693-725, 1986.

[3] Qui, Y., Sun, A. Kuffel, E. Improved Dielectric Strength of SF6 Gas with a Trichlorotrifluoroethane Vapor Additive Issue: 6, Vol EI-22, p 763-768, 1987.

[4] Pham,V. D., Thuries E., Martin J. Patent EP19910117923, 12/20/1995.

[5] Fleischer L., Müller H.J., Poth R., Späck H. Patent EP19950940161, 09/30/1998.

[6] Chritophorou L.G., Olthoff J.K., Van Brunt RJ Van Sulfur Hexafluoride and the Electric Power Industry IEEE Electrical Insulation Magazine Vol 13, N5 p 20-24, 1997.

[7] D. Koch, SF6 properties, use in MV and HV switchgear, ECT188, Schneider Electric, 1997.

[8] JANAF, Thermochemical tables, $4^{\text {th }}$ edn, MW Chases (ed.), J Phys. Chem. Ref Data, N9, 1998.

[9] André P. Partition functions and concentrations in plasmas out of thermal equilibrium IEEE Transactions on Plasma Science, Vol 23, issue 3, p 453-458, 1995.

[10] Rochette D., Bussière W., André P., Composition, Enthalpy, and Vaporization Temperature Calculation of $\mathrm{Ag}-\mathrm{SiO}_{2}$ Plasmas with Air in the Temperature Range from 1000 to $6000 \mathrm{~K}$ and for Pressure Included between 1 and 50 bars, Plasma Chemistry and Plasma Processing, Vol 24, №3, p 475-492, 2004.

[11] K.P. Brand and J. Kopainsky, Particle Densities in a Decaying SF 6 Plasma, Appl Phys, Vol 16, p 425-432, 1978.

[12] Andre P, Etude d'un plasma de SF 6 hors d'équilibre thermique, (in French), J. Phys. III, Vol 7, p 1339-1359 1997.

[13] G. Speckhofer, R. Gilles, W. Smith, M. Bures, A consistent Set of Thermodynamic Properties and Transport Coefficients for High-Temperature Plasmas, in proc 14 th ISPC, ed hrabovsky, Czech republic 1999. 